\title{
Human Security in Southeast Asia: 20 Years in Review
}

\author{
Surin Pitsuwan and Mely Caballero-Anthony
}

\begin{abstract}
The concept of human security gained prominence in Southeast Asia in the aftermath of the Asian financial crisis of 1997-1998. In a rapidly changing ASEAN, the list of human insecurities covers issues of both development and security, and fall within the ambit of both freedom from want and freedom from fear. But while human security has gained traction 20 years since the 1994 UNDP Human Development Report, more needs to be done to translate discourse into action. This article argues that in order to advance human security ASEAN states must be imbued with the political will to act decisively in addressing human insecurities and to work with other actors in promoting protection and empowerment of people and communities.
\end{abstract}

Keywords ASEAN, ASEAN Political and Security Community, human rights, community security, R2P

\section{Introduction}

The concept of human security has made significant advances since it was first promulgated in the United Nations Development Programme's (UNDP) Human Development Report of 1994. The report, which was largely inspired by the work of Mahbub ul Haq, advocated shifting the security reference from the nationstate to individuals and communities. As one of the pioneering advocates of human security, Haq had argued for a new concept of security "that is reflected in the lives of the people, not in the weapons of our country" (Haq 1994, 1). According to Haq, security should be interpreted as "security of people, not just security of territory; security of individuals, not just security of nations; security through development, not security through arms; and security of all the people everywhere-in their homes, in their jobs, in their streets, in their communities, in their environment" (ibid.). In its simplest form, human security is therefore about protecting individuals. It goes to the very heart of the questions "security 
for whom?" and "whose security?"

The 1994 UNDP Human Development Report, which offered the first operationalization of the human security concept, outlines two main aspects of human security. Human security means "first, safety from such chronic threats as hunger, disease and repression. And second, it means protection from sudden and hurtful disruptions in the patterns of daily life-whether in homes, in jobs or in communities." The report further identifies seven elements of human security, namely, economic security, food security, health security, environmental security, personal security, community security, and political security. Given the breadth of the UNDP's operation, the truncated version- "freedom from fear and freedom from want"-became the more common definition of human security (UNDP 1994, 23).

Although the human security concept has generated robust policy debate and controversy since its inception, and has inspired significant academic research, traction within the domestic and foreign policies of states remains elusive. Such is the paradox of human security: while the concept makes for a compelling normative framework to guide the focus of security from the state to individuals and communities, progress on moving it beyond discourse to action has been less than impressive. The paradox becomes even more interesting given the rising resonance of the concept in many international meetings over the course of the last 20 years. There is also the greater realization and appreciation that human security issues-be they economic, food, health, or environmental security-are critical to national security. More significantly, there is certainly a growing constituency of actors, both state and non-state, advocating human security as an effective framework for addressing many of the security challenges confronting the international community at large. In 1998, for example, a group of like-minded foreign ministers of a few countries came together and formed among themselves the Human Security Network (HSN). Under the leadership of Knut Vollebaek of Norway and Lloyd Axworthy of Canada, the Network began an active advocacy of the human security concept in various fora of the world. And they have made some impressive progress in their cause. This is best reflected in the 2005 United Nations report entitled In Larger Freedom. Former UN Secretary-General Kofi Annan explains:

When the UN Charter speaks of "larger freedom," it includes the basic political freedoms to which all human beings are entitled. But it also goes beyond them, encompassing what President Franklin Roosevelt called "freedom from want" and "freedom from fear." Both our security and our principles have long demanded that we push forward all these frontiers of freedom, conscious that progress on one depends on and reinforces progress on the others. In the last 60 years, rapid technological advances, increasing economic interdependence, globalization, and dramatic geopolitical change have made this imperative only more urgent (Annan 2005). 
Against this background, the aim of this article is to assess the progress in the mainstreaming of human security in Asia, particularly in Southeast Asia. We examine the ways in which the human security narrative has evolved and has been diffused in Southeast Asia, and importantly, the extent to which human security has actually taken hold in the region. We are particularly interested in the degree to which human security has become the strategic framework driving the security agenda of Southeast Asia, and the Association of Southeast Asian Nations (ASEAN) more particularly. In doing so, we argue that 20 years since the appearance of the concept of human security in the Human Development Report, and following the formation of the Human Security Network in 1998, it could well be that the imperative of advancing human security is more a matter of generating political will and finding innovative ways to promote the concept than of finding compelling reasons for why human security matters.

\section{Human Security Then}

Scholars have generally described the evolution of human security over the last 20 years in terms of two phases. The first phase began in 1997 when the emergent concept was embraced by the Japanese and Canadian governments and made part of their official foreign policies. While the two countries were regarded as the first generation advocates of human security, one can differentiate between their two approaches.

The Canadian approach has been more focused on the freedom-from-fear aspect of human security. This was clearly reflected in a foreign policy document which stated that human security "in essence, means safety for people from both violent and non-violent threats ... a condition or state of being characterized by freedom from pervasive threats to people's rights, their safety, or even their lives" (DFAIT 2000). The specific emphasis on freedom from fear seemed to have stemmed from the images of human violence and misery in African states such as Rwanda, Somalia, and Sierra Leone. These were shameful scars on the international community's efforts to respond and vivid illustrations of its failure to avert human violence and catastrophe. From this perspective, human security is aimed at reducing conflicts, preventing mass atrocities, and protecting people from physical threats to their safety and well-being.

The Japanese approach is tuned more towards freedom from want. As articulated by former Japanese Prime Minister Keizo Obuchi, human security is "the key which comprehensively covers all the menaces that threaten the survival, daily life, and dignity of human beings and strengthens all efforts to confront those threats" (Obuchi 1998). Among the menaces that were outlined were environmental degradation, violations of human rights, transnational organized crime, illicit drugs, refugees, poverty, anti-personnel landmines, and 
infectious diseases such as AIDS (Ministry of Foreign Affairs of Japan 1999). An obvious difference between Japan's approach and that of Canada is the comprehensive listing of human security threats. The Japanese perspective is that the current world situation has brought about a "diversification of threats," and the development of the idea of human security signifies recognition of the many threats to the dignity and survival of individual human beings. Thus, "human security can only be ensured when the individual is confident of a life free of fear and free of want" through an inclusive agenda addressing human needs (Takasu 2000).

The lack of convergence on the definition of what exactly should be the focus of human security extended beyond policy circles to the academic community. The main critique was that the concept was too broad and unnecessarily vague (Paris 2001; Liotta and Owen 2006). As one report noted, unless one focuses on specific issues human security as a concept loses its utility (Harvard University Conflict Resolution Project 2000). Sverre Lodgaard (2001) was among many writers who argued for a narrower definition of human security confined to "vulnerability to physical violence during conflict." Similarly, Astri Suhrke (1999) argued that human security should focus only on "vulnerability" as its defining feature, which in this instance would refer to three categories of victims: those of war and internal conflict; those living at or below subsistence levels; and those who are victims of natural disasters. To these analysts, the concept of human security would be best served if it were to be confined to freedom from fear of man-made physical violence, referred to as direct, personal violence. This perspective is very close to the Canadian approach to human security which privileges the notion of freedom from fear.

Other scholars preferred a more flexible interpretation of the human security concept. One definition sought to view the "bases of [human] security as a comprehensive and integrated matrix of needs and rights, from which all individual and social values can flourish and be optimized" (van Ginkel and Newman 2000). There was also an earlier attempt to conceptualise human security by identifying the "objective-the ultimate ends-of all security concerns" as "human survival, well-being and freedom" (Chen 1995, 137-145).

The Canadian focus on freedom from fear led to its sponsorship of the International Commission on Intervention and State Sovereignty (ICISS) which introduced the concept of the Responsibility to Protect (R2P) in its 2001 report. R2P advanced the idea of "sovereignty as responsibility." It framed the contending issues of sovereignty and intervention in terms of the responsibility to protect. The central proposition of the ICISS report was this:

- State sovereignty implies responsibility, and the primary responsibility for the protection of its people lies with the state itself.

-Where a population is suffering serious harm as a result of internal war, insurgency, 
repression or state failure, and the state in question is unwilling or unable to halt or avert it, the principle of non-intervention yields to the international responsibility to protect (ICISS 2001, xi).

The bold, yet innovative, semantic crafting of "sovereignty as responsibility" drew a mixed response from the international community. Many states, particularly those in Asia, were skeptical of $\mathrm{R} 2 \mathrm{P}$-with some perceiving the notion as a Trojan horse for stronger states to intervene in the affairs of weaker states. Nevertheless, the idea that a state can be held responsible for its failure to protect its own citizens from human rights atrocities was a dramatic departure from the sacrosanct principle of non-interference in the internal affairs of states.

Thus, even as the human security concept was being hailed as the paradigm most reflective of the security challenges of the post-Cold War era, the first attempts at promoting it in the global community met with resistance. Nevertheless, the efforts did create enough momentum to generate critical support for its broad objectives. The language of human security became an important point of reference for a growing constituency of countries and civil society groups. These actors pushed for human security to be the new paradigm for setting the global security agenda. The aim was to elevate human security to the strategic level, as a driver of security policy and as a compelling framework for multilateral cooperation.

One important constituency has been the Human Security Network (HSN) established in 1999 by Norway in partnership with the Canadian and Swiss governments. ${ }^{1}$ The HSN identified 10 important issues for the human security agenda, namely, anti-personnel landmines, small arms, children in armed conflict, international humanitarian and human rights law, international criminal proceedings, exploitation of children, safety of humanitarian personnel, conflict prevention, transnational organized crime, and resources for development (Human Security Network 1999, 2-4).

And, while several countries in Asia were initially skeptical of the concept of human security, the Japanese government initiated the establishment of the Commission on Human Security (CHS) in $2001 .^{2}$ A critical mission of the Commission was to define the concept and the agenda of human security more clearly, and in turn, promote greater understanding of the concept given the concerns at that time about the implications for state sovereignty and the noninterference principle. Co-chaired by Sadako Ogata of Japan and Professor Amartya Sen, a Nobel Laureate in Economics, the Commission issued the report Human Security Now, which described human security as encompassing both freedoms-freedom from want and fear, as well as freedom to live in dignity. The significant inclusion of "freedom to live in dignity" was to stress the facet of empowerment, which enables individuals and communities to protect themselves against the range of human security threats that they face. The findings of the 
Commission reflected the combined perspectives of protection for people under threats (Ogata's emphasis) and human development and empowerment (Sen's emphasis).

From the above developments, two observations can be made. First, the initial attempt to socialize the concept of human security in the international community generated more division than convergence on the objectives of human security. Aside from the criticism that human security was too broad and unnecessarily vague, there was also the split between those that preferred a narrower definition of human security-i.e. freedom from fear-and those that were more comfortable with a more development-oriented notion of human security that emphasized the impact of poverty, food, and health insecurity, among others, particularly on the poor, women, children and the elderly-that is, on the most vulnerable sections of society. Underpinning this division is the question of whether human security should include the possibility of the use of force through humanitarian intervention to protect individuals from threats of physical violence. As noted earlier, the introduction of R2P only heightened this concern.

Second, despite the divisions, efforts at promoting human security continued, with more attention given not only to bridging the gap in the understanding and application of the concept, but also to advancing human security as a useful policy framework in defining areas for multilateral cooperation at various levels in the international arena. Japan, together with Slovenia and Thailand, has been leading this effort through the United Nations Trust Fund for Human Security. Among the areas that have been identified are developmental assistance and humanitarian projects. In brief, efforts to mainstream human security continued despite the skepticism and criticisms. The seeds of human security had been planted, and slowly but surely, the language of human security began to creep into the security lexicon of some parts of the global community. This ushered in the second phase in the development of the human security concept.

\section{Human Security Now}

As discussed above, the challenges that confronted the promotion of human security did not deter its advocates from pushing ahead with the goals of mainstreaming the concept in the security practices of states. After a decade of advocacy, the most visible impact was the European Union's (EU) adoption of the 2004 Barcelona Report, entitled A Human Security Doctrine for Europe (Study Group on Europe's Security Capabilities 2004). The report supported the notion of human security as the security doctrine underpinning the EU's external relations, citing three reasons: first, morality (all human life is equal and all humans have the right to live in security and with dignity); second, legal 
(there is universal acceptance of promoting and protecting human security and human rights); and third, enlightened self-interest (the EU's interest can be met by addressing the insecurities of an interconnected world). This was followed by the 2007 Madrid Report, A European Way of Security, which aimed to add more depth to the EU's human security doctrine in pragmatic and institutional terms, with more focus given to crisis management, conflict prevention, and civilmilitary cooperation (Human Security Study Group 2007). While not without its own challenges and detractors, some EU countries (Finland, for example) have used their presidency of the EU to push human security forward. Despite the notable progress owing largely to the efforts of the EU's epistemic communities, it has been observed that the full thrust of the human security doctrine has yet to be fully seen in the EU's Common Security and Defence Policy (Christou 2014).

At the UN, two developments are salient as indicators of progress in advancing the human security concept: inclusion of the concept in UN proceedings and elaboration of the R2P principle. Following the 2003 Report of the Commission on Human Security, the Japanese government convened a Friends of Human Security (FHS) meeting aimed at disseminating the concept and keeping up the momentum of discussions of human security at UN fora. The efforts paid off in 2010. The UN Secretary-General's report in June that year reflected the first formal discussion of human security at the UN General Assembly. The report was followed by a UN General Assembly resolution on human security in July 2011. In April 2012, a second report by the UN SecretaryGeneral on human security was released which offered a common understanding of the concept. The 2012 report, which was adopted by the UN General Assembly in September 2012, proposed that human security include freedom from fear and freedom from want, as well as a protection and empowerment framework quite distinct from the notion of R2P (UN General Assembly 2012).

Meanwhile, the debate on R2P had also progressed significantly following its first iteration in 2001, and it gained widespread international acceptance at the World Summit in 2005. However, the notion of R2P adopted in 2005 had a starkly different articulation from that advanced by the ICISS report. The basic premise of the $2005 \mathrm{R} 2 \mathrm{P}$ is that each state bears the responsibility to protect its citizenry from genocide, ethnic cleansing, war crimes, and crimes against humanity. While one notes that the reformulated version of R2P is much narrower in scope and applies only to four atrocity crimes, it nevertheless represents a significant normative shift in that it focuses on the victims of atrocities, with states, singularly, and the international community, as a collective, responsible for developing national and international measures to protect populations from grave and unconscionable harm. Hence, in the case of a state either manifestly unable or unwilling to discharge its responsibility to safeguard its populace from genocide and mass atrocities, the responsibility to protect beleaguered populations lies with the international community as a whole. 
In sum, the second phase of human security saw notable progress beyond the debate on what the concept means to disseminating and developing the concept as a useful policy framework in addressing a slew of human security challenges. The key challenges moving forward then are, first, how to convince states to usefully apply the human security approach in their own domestic and foreign policies, and second, how states can work with a broad spectrum of actors to address the range of insecurities besetting their own communities.

\section{Human Security in Southeast Asia: Mapping Points of Inflection}

The narrative on Southeast Asia's attitudes toward, and interpretations of, human security in many ways mirrors the development and progress of the concept at the global level. What started as a cautious stance in the region on human security evolved into a more nuanced position influenced largely by the changing security dynamics in the region and beyond.

While human security has been regarded by many in ASEAN as a novel concept, one could argue that many of its elements are actually complementary to the region's own notion of "comprehensive security." Within the framework of comprehensive security, security "goes beyond (but does not exclude) the military threats to embrace the political, economic and socio-cultural dimensions" (Alagappa 1998, 624). As an ASEAN security analyst points out, the region has always regarded security as multi-dimensional and comprehensive in nature, as reflected in many ASEAN documents including the ASEAN Concord of 1976, and ASEAN's Treaty of Amity and Cooperation in Southeast Asia, also signed in 1976 (Hassan 1995).

Against the region's notion of comprehensive security, human security is not necessarily an alien concept (Acharya and Acharya 2000). Yet, while comprehensive security indeed offers a broader conceptualization of security, it is still very much state-centric in nature-the security reference is still the state and not individuals and communities. Hence, in Southeast Asia, comprehensive security was for a long time associated with the notion of security of regimes from all possible threats. The privileging of state security also meant that issues of human rights and human security were secondary to concerns about regime security. This was particularly the case for authoritarian regimes in ASEAN.

And so it was not unusual that, as the discourses on human security filtered through the region, many officials claimed its lack of relevance, particularly when the idea of R2P emerged. During that period, the regional security environment was often described as benign largely due to ASEAN. It was ASEAN that turned Southeast Asia from what could have been the Balkans of the East into one of the more peaceful and economically prosperous regions in the world. One would often hear ASEAN officials-and even the region's political elites-declare that an 
R2P-like crisis could not conceivably happen in ASEAN. What was not discussed was the fact that one of the most tragic human atrocity cases happened in Southeast Asia's own backyard: In Cambodia, approximately two million people were killed between 1976 and 1979 under the Khmer Rouge regime.

\section{Asian Financial Crisis}

It took the impact of the Asian financial crisis (1997-1999) for human security to find some traction - at least in the policy discourses in the region. The region's experience during the crisis revealed how, in an interconnected world, a financial crisis can easily spiral into a contagious crisis of magnified proportions, and within a short period of time. There have already been numerous published studies detailing the impact of the 1997 Asian financial crisis (e.g., JCIE 1998; World Bank 1998), but briefly, the nature and range of the impacts are highlighted below.

- Threat of economic collapse: While countries in the region were affected to varying degrees depending on their specific circumstances, in general, the crisis dealt a severe blow to economies, as seen in massive public and private debt, rising inflation, massive unemployment, and economic dislocation. At the height of the crisis ASEAN currencies depreciated by 30-40 per cent. And in the case of Indonesia, the rupiah depreciated at one time by as much as 80 per cent.

- Breakdown of public order in response to ethnic tensions: The impact of economic crisis threatened the social fabric of multi-ethnic societies in ASEAN. This was seen in Indonesia when ethnic Chinese bore the brunt of public unrest in the wake of the unexpected economic downturn. The crisis also triggered ethnic tensions between Christians and Muslims in the Indonesian provinces of the Moluccas and West Papua.

- Loss of political legitimacy and pressure for political change: In Indonesia, the Suharto regime of 33 years was brought down within less than a year of the onset of the economic crisis, while other governments in the region faced serious challenges, as in the cases of Malaysia and Thailand.

- Increased labor migration and tensions between ASEAN states: The sudden economic downturn led to a mass exodus of labor migrants who had sought livelihoods within and across national borders. Migration is often seen as a people's crisis but it can also contribute to bilateral state crises. The repatriation of migrant workers led to bilateral tensions, for instance, between Malaysia and Indonesia with regard to Indonesian foreign workers in Malaysia, between Thailand and Myanmar with regard to Myanmar foreign workers in Thailand, and between Indonesia and Singapore with regard to Indonesian foreign workers in Singapore.

- Rising incidence of domestic violence and social problems: This was particularly apparent among the communities whose livelihoods were severely affected by the crisis.

None of the affected ASEAN countries had anticipated the severity of the impacts 
nor the flow-on effects on the security of their respective regimes. The notion that comprehensive security may no longer be adequate to meet emerging challenges like the 1997 financial crisis certainly led to some soul-searching in the policy communities in the region. The impetus to rethink security was best encapsulated in a speech by the then Thai foreign minister in which he stated: "I am proposing ... that we here at the [Post Ministerial Conference] consider setting up an ASEAN-PMC Caucus on Human Security [for] mapping out steps and strategies for long-term approach to the cure for and prevention of 'human insecurity' in our region" (Pitsuwan 1998).

The 1997 crisis galvanised disparate efforts by a number of civil society organizations which had for some time been critical of the region's state-centric approach to security. During the height of the crisis, the language of human security resounded from the many voices of civil society groups across ASEAN urging their own governments to adopt human security as the new framework guiding national policies in both development and security. The call for a rethinking of security became more resonant as the region experienced more convulsions.

\section{Multiple Humanitarian Crises}

In the 10-year period after the concept of human security was first introduced in 1994, Southeast Asia was hit by a number of crises apart from the Asian financial crisis. There were humanitarian crises resulting from the political upheavals in East Timor in 1999; the emergence of new transborder security threats such as transnational crime (drug trafficking and human smuggling); environmental crises (haze episodes); health crises resulting from the severe acute respiratory syndrome (SARS) pandemic in 2003 and Avian flu in 2009; and "new" terrorism and extremism threats triggered by the September 2001 terrorist attacks in the United States. The region witnessed even more devastating human security crises with the 2004 earthquake and tsunami which saw the loss of nearly a quarter of a million lives. And, just as ASEAN was coming to grips with the multiple types of crises confronting the region, one of its member states, Myanmar, had its own Saffron Revolution in 2007, which saw a series of violent demonstrations led by the country's Buddhist monks against the military regime resulting in a number of civilian deaths. A year later, in 2008, cyclone Nargis killed thousands in the country, a disaster aggravated by the perceived indifference of the ruling regime to the victims.

The series of crises experienced by the region represented critical points of inflection for ASEAN member states to seriously assess the then pervasive view that the notions of human security and R2P were not relevant to ASEAN. Subsequently, ASEAN crafted a vision of an ASEAN Community anchored by three pillars: the ASEAN Political-Security Community (APSC), ASEAN Economic Community (AEC), and ASEAN Socio-Cultural Community (ASCC). 
This vision was geared toward building a community that is people-centered, and where the populace live in a "just, democratic and harmonious environment" defined by "shared prosperity" and a "caring and sharing community" (ASEAN 2009). This response reflected an evolving development within the regional association to be more pro-active in addressing human security issues.

In fact, ASEAN's collective engagement in the East Timorese crisis of 1999, the humanitarian assistance to victims of the Indian Ocean tsunami of 2004, and the relief and reconstruction efforts in post-Cyclone Nargis in Myanmar of 2008 could all be said to reflect human security considerations, at least in the minds of ASEAN leaders and officials.

A closer look at the APSC Blueprint document (adopted in 2009) reveals a number of policy initiatives and measures developed to address a host of emerging regional security challenges. The Blueprint sets out five strategic thrusts aimed at bringing ASEAN's political and security cooperation to a "higher plane" where states can work more closely to address transnational issues and ensure the safety and well-being of their societies. These are conflict prevention, conflict resolution, post-conflict peace building, political development, and norm shaping and sharing. ${ }^{3}$

Aside from the APSC, ASEAN also adopted a Charter, in 2007, that codified the norms of inter- and intra-state conduct, including respect for fundamental freedoms and the promotion and protection of human rights. This was followed by the establishment of the ASEAN Intergovernmental Commission on Human Rights (AICHR) in 2009 and the ASEAN Commission on the Promotion and Protection of the Rights of Women and Children (ACWC) in 2010. Arguably, these regional institutions present opportunities for the promotion of human security by, among other things, embedding a human rights culture in ASEAN, developing conflict prevention norms in the region, as well as encouraging the development of the capacity of states to prevent and respond to the various protection concerns that might affect the security of individuals and communities within ASEAN. With these institutions, it could very well be that human security and the principles of $\mathrm{R} 2 \mathrm{P}$ are starting to be demystified and advances are being made toward the ultimate goal of mainstreaming human security practices in the region.

\section{Whither Human Security in the ASEAN Community in 2015 and Beyond?}

Many observers have commended the significant progress that ASEAN has achieved in building regional capacity to address the different types of security challenges. The ASEAN of today, compared with that of a decade ago, has certainly come a long way in building up its image as a credible regional body. 
Table 1. Displaced Persons in Myanmar, Philippines, Indonesia and Thailand (2013)

\begin{tabular}{|c|c|c|c|}
\hline & Internally displaced Persons & Refugees & Stateless Persons \\
\hline Myanmar & 632,000 & $\begin{array}{l}415,343 \\
\text { (from Myanmar) }\end{array}$ & 808,075 \\
\hline Philippines & 16,905 & - & 6,015 \\
\hline Indonesia & $170,000^{(1)}$ & $\begin{array}{l}15,168 \\
\text { (from Indonesia) }\end{array}$ & \\
\hline Thailand & - & $\begin{array}{l}82,460 \\
\text { (most from Myanmar) }\end{array}$ & 506,197 \\
\hline
\end{tabular}

Note: (1) 2011.

Sources: UNHCR 2013; for Indonesia, International Displacement Monitoring Centre 2011.

From a weakened institution after the 1997 Asian financial crisis, ASEAN is now claiming its centrality in the regional multilateral security architecture. Yet, we argue that as far as institutionalizing human security in its security practices, for a number of reasons ASEAN still has a long way to go.

First, much work needs to be done to ensure the economic security of its population of 600 million. Narrowing the development gaps within ASEAN remains an elusive goal with a large percentage of the region's population still living below the poverty line. Two of the ten ASEAN countries are still among the poorest in the world, with per capita gross domestic product (GDP) of less than US $\$ 1,000$ (IEA 2013). From the perspective of freedom from want, meeting basic needs is still a huge challenge. For instance, more than 130 million people in Southeast Asia still do not have access to electricity; a vast majority of them live in rural or remote areas (ibid.). Such lack of access to energy is particularly detrimental to local communities whose freedom from food and economic insecurity are compromised as a result.

Second, in a post-Charter ASEAN, there continue to be a number of communities that suffer acute insecurities, including displacement, as a result of ongoing conflicts as demonstrated by the data in Table 1 .

Although there are efforts by concerned governments to find a political solution to the different conflicts-with some showing progress, as in the case of the recently inked peace agreement between the government of the Philippines and the Moro Islamic Liberation Front (MILF) - they have already exacted a high toll on the lives of people in the affected communities in the region. In Southern Thailand, unrest among the Malay-Muslim population has led to conflict with the government that has cost over 6,000 lives since January 2004. Human insecurity remains a real challenge for the ethnic minority in a mainly Buddhist state.

Aside from these conflicts, there is also the insecurity of certain minority groups such as the Rohingya communities in Myanmar. As non-citizens, 
Rohingyas are deprived of many fundamental rights, including freedom of movement, education, marriage, and employment. They are also exposed to human rights violations such as arbitrary detention, forced labor, rape, torture, and forcible relocation. Until the plight of the Rohingyas is addressed, the issue will continue to be a blight on ASEAN's goal of realizing a political and security community that is just, tolerant, and democratic.

The complex ethnic and religious make-up of some countries in the region has created flashpoints for the discrimination and marginalization of some groups by others. In some cases, states have been responsible for the discrimination against minority groups, or at least, been complicit in the violence perpetrated against them. Threaded through these narratives is the link between conflict and development. Conflict-affected areas are among the worst performers in terms of poverty and human development. As long as conflict exists, it will be difficult to narrow the development gap. Without stability, the cycle of poverty will continue. Although poverty has seldom been the primary reason for the grievances in the various areas, the insecurities created by poverty may act as a multiplier to conflicts. Within such a context of conflict and instability, it is difficult to narrow the development gaps, an agenda seen as an integral dimension of the ASEAN Community.

Third, as ASEAN continues to deepen economic integration, there are also the multiple insecurities faced by people on the move, such as the thousands of migrant workers that are vulnerable and in need of protection from human rights abuses and violence. While ASEAN has made some strides through the 2007 ASEAN Declaration on the Protection and Promotion of the Rights of Migrant Workers, this convention will remain weak unless all countries that are host to migrant workers observe and protect the rights of these communities. Importantly, protection becomes a challenge as long as host countries that are unable to provide protection hide behind the cloak of non-interference.

Fourth, there are the complex human insecurities brought on by the increasingly frequent natural disasters such as cyclones and earthquakes. As the global environment adjusts to the new normal of intense weather patterns, the ASEAN region's vulnerability to more frequent cyclones of severe magnitude becomes more acute. This means that more people in ASEAN will need better protection from natural disasters, which in turn demands increased efforts by governments to build greater capacity to make their communities more disasterresilient.

These four reasons are certainly not exhaustive. In a rapidly changing ASEAN, the list of human insecurities covers both the issues of development and security, and falls within the ambit of both freedom from want and freedom from fear. Thus, against the range of security challenges facing ASEAN, there are strongly compelling reasons to adopt a human security approach and use the concept as a guiding framework for national and regional policies. There is 
also no reason why the principles of $\mathrm{R} 2 \mathrm{P}$, particularly the principle of conflict prevention, cannot be institutionalized in the region. It is noteworthy that since 2005 several ASEAN member countries have already engaged in the ongoing development of the R2P principle through their respective contributions to the informal dialogues of the UN General Assembly as well as participation in the Group of Friends of R2P. But more should certainly be done to promote the principles of conflict prevention and move toward advancing mechanisms for conflict management and resolution if ASEAN is to give substance to creating a community in Southeast Asia, with human security as its overarching framework.

\section{Conclusion}

We began this article acknowledging that human security has achieved important milestones. Since the 1994 UNDP Report, and following the 1998 Lysøen Declaration that served as the global compact among a coalition of governments to work together on global challenges that threatened individuals and communities, human security has gone beyond being a "new" alternative concept of security to one that is critically important in an era of global power transition and uncertainties.

ASEAN and the wider East Asian region comprise one of the key nodes in this changing global landscape. Having been at the center of many of the human security crises that have taken place in the last 15 years, the region has had to seriously reassess its security concepts and approaches. Therefore, the adoption of an ASEAN Political and Security Community is but one of the many manifestations of the kind of security rethinking that is ongoing in Southeast Asia. As the region becomes more engaged with, and integrated into, the global community, there will be more compelling reasons for states to be imbued with the political will to work collaboratively in addressing complex human insecurities.

Indeed, given the breadth and depth of an increasingly interconnected world, the regional and the global community will need to be infused with new thinking on how best to promote and advance human security-more decisively, more boldly. This requires no less than a renewed compact on human security. Thus, 15 years after the Lysøen Declaration, a renewed compact on human security should aim to bring together a range of actors, extending beyond states to include civil society groups and other constituencies, to craft new pathways for effective international collaboration and cooperation for addressing 21 st century threats to human security. 


\section{Notes}

1. The network comprises Austria, Canada, Chile, Costa Rica, Greece, Ireland, Jordan, Mali, the Netherlands, Norway, Slovenia, South Africa (observer), Switzerland, and Thailand. Lloyd Axworthy (Canada) and Knut Vollebaek (Norway) started the Human Security Network (HSN) with the Lysøen Declaration (1998) which committed its members to a "framework for consultation and concerted action in the areas enhancing human security, promoting human rights, strengthening humanitarian law, preventing conflict and fostering democracy and good governance." See: http://www.mzz.gov.si/en/ foreign_policy/foreign_policy/human_security_network_hsn/(accessed December 10, 2013).

2. The Commission on Human Security brought together twelve prominent international figures, including Mrs. Sadako Ogata (former UN High Commissioner for Refugees) and Professor Amartya Sen (1998 Nobel Laureat in Economics). Surin Pitsuwan served as one of the Commissioners.

3. The ASEAN Political-Security Community (APSC) also provides for the establishment of an early warning mechanism in ASEAN to prevent conflict, and to promote and protect human rights, in the shape of the ASEAN Intergovernmental Commission on Human Rights (AICHR) (ASEAN 2009).

\section{References}

Acharya, Amitav, and Arabinda Acharya. 2000. "Human Security in the Asia Pacific: Puzzle, Panacea and Peril." CANCAPS Bulletin 27 (November): 2-3.

Alagappa, Muthiah. 1989. "Comprehensive Security: Interpretations in ASEAN Countries." In Asian Security Issues: Regional and Global, eds. Robert Scalapino, Seizaburo Sata, Jusuf Wanandi, and Sung-Joo Han. Berkeley, CA: Institute of East Asian Studies, 5078.

Alagappa, Muthiah. 1998. Asian Security Practices: Material and Ideational Influences. Stanford: Stanford University Press.

Annan, Kofi. 2005. "In Larger Freedom: Decision Time at the UN." Foreign Affairs 84 (3). http://www.foreignaffairs.com/articles/60799/kofi-annan/in-larger-freedomdecision-time-at-the-un (accessed September 10, 2013).

ASEAN. 2008. “The ASEAN Charter.” Jakarta: ASEAN Secretariat. http://www.asean.org/ archive/publications/ASEAN-Charter.pdf (accessed August 14, 2014).

ASEAN. 2009. "ASEAN Political-Security Community Blueprint." Jakarta: ASEAN Secretariat. http://www.asean.org/archive/5187-18.pdf (accessed August 14, 2014).

Chen, Lincoln. 1995. "Human Security: Concept and Approaches." In Common Security in Asia: New Concepts of Human Security, eds. Tatsuro Matsumae and Lincoln Chen. Tokyo: Tokai University Press, 137-145.

Christou, George. 2014. “The European Union's Human Security Discourse: Where are We Now?” European Security (3) 364-381.

DFAIT (Department of Foreign Affairs and International Trade of Canada). 2000. Freedom 
from Fear: Canada's Foreign Policy for Human Security. Ottawa: Department of Foreign Affairs and International Trade of Canada.

Haq, Mahbub ul. 1994. "New Imperatives of Human Security." RGCIS Paper 17. New Delhi: Rajiv Gandhi Institute for Contemporary Studies.

Harvard University Conflict Resolution Project. 2000. "The Human Security Report." Unpublished manuscript.

Hassan, Mohamed Jawhar. 1995. "Asian Perspective on Security." In Common Security in Asia: New Concepts of Human Security, eds. Tatsuro Matsumae and Lincoln C. Chen. Tokyo: Tokai University Press, 137-145.

Human Security Network. 1999. “A Perspective on Human Security.” Chairman's Summary at the 1st Ministerial Meeting of the HSN, Lysøen, Norway, May 20, 2-4.

Human Security Study Group. 2007. A European Way of Security: The Madrid Report of the Human Security Study Group, Madrid, November 8.

ICISS (International Commission on Intervention and State Sovereignty). 2001. The Responsibility to Protect. Ottawa: International Development Research Centre.

IDMC (Internal Displacement Monitoring Centre). 2011. "Submission from the IDMC of the Norwegian Refugee Council (NRC) to the Universal Periodic Review Mechanism Established by the Human Rights Council in Resolution 5/1 of 18 June 2007." November 21. http://www.internal-displacement.org/assets/library/Asia/Indonesia/ pdf/IDMC-UPR-submission-Indonesia-Nov-2011.pdf (accessed August 19, 2014).

IEA (International Energy Agency). 2013. Southeast Asia Energy Outlook: World Energy Outlook Special Report. Paris: IEA.

JCIE (Japan Centre for International Exchange) and Institute of Southeast Asian Studies (ISEAS). 1998. The Asian Crisis and Human Security. Tokyo: JCIE.

Liotta, Peter H., and Taylor Owen. 2006. "Why Human Security?" The Whitehead Journal of Diplomacy and International Relations 7 (1): 37-54.

Lodgaard, Sverre. 2001. "Human Security: Concept and Operationalization." Oslo: Norwegian Institute of International Affairs. http://www.cpdsindia.org/ conceptandoperationalization.htm (accessed September 11, 2013).

Ministry of Foreign Affairs of Japan. 1999. Diplomatic Bluebook 1999. Tokyo: Ministry of Foreign Affairs of Japan.

Obuchi, Keizo. 1998. Opening Remarks at an Intellectual Dialogue on Building Asia's Tomorrow. Tokyo, December 2. http://www.jcie.or.jp/thinknet/tomorrow/1obuchi. html (accessed August 20, 2014).

Paris, Roland. 2001. "Human Security: Paradigm Shift or Hot Air?” International Security 26 (2): 87-102.

Pitsuwan, Surin. 1998. Opening Statement at the Post-Ministerial Conference $9+10$ Session, Manila, Philippines, July 28. http://www.asean.org/communities/aseanpolitical-security-community/item/statement-by-he-mr-surin-pitsuwan-ministerof-foreign-affairs-of-thailand-at-the-pmc-910-session-agenda-item-2-a-c-manilaphilippines-28-july-1998 (accessed August 20, 2014).

Study Group on Europe's Security Capabilities. 2004. A Human Security Doctrine for Europe: The Barcelona Report of the Study Group on Europe's Security Capabilities. Barcelona, September 15. http://www.consilium.europa.eu/uedocs/cms_data/docs/ pressdata/solana/040915CapBar.pdf (accessed August 20, 2014).

Suhrke, Astri. 1999. "Human Security and the Interests of States." Security Dialogue 30 (3): 
265-276.

Takasu, Yukio. 2000. Statement at the Third Intellectual Dialogue on Building Asia's Tomorrow. Director-General of Multilateral Cooperation Department, Bangkok, June 19.

UNDP. 1994. Human Development Report 1994. New York: Oxford University Press.

UN General Assembly. 2012. Follow-up to Paragraph 143 on Human Security of the 2005 World Summit. A/Res/66/290. http://www.un.org/en/ga/search/view_doc. asp?symbol= A/RES/66/290 (accessed August 16, 2014).

UNHCR. 2013. “2013 UNHCR Regional Operations Profile-South-East Asia.” UNHCR Statistical Snapshots. http://www.unhcr.org/pages/4b17be9b6.html (accessed December 27, 2013).

van Ginkel, Hans, and Edward Newman. 2000. "In Quest of 'Human Security"' Japan Review of International Affairs 14 (1): 59-82.

World Bank. 1998. East Asia: The Road to Recovery. Washington: World Bank.

Surin Pitsuwan is currently president of Thammasat University in Bangkok. He has had a distinguished career of national and international service. He was elected a member of the Thailand Parliament eight times and also served as Thailand's foreign minister from 1997 to 2001. From 2008 to 2012 he was Secretary-General of ASEAN. Earlier he was appointed a member of the UN Commission on Human Security and also the Advisory Board of the UN Human Security Trust Fund. He holds a PhD in Political Science and Middle Eastern Studies from Harvard University and has written widely on peace, conflict resolution, and human security issues. E-mail: s.pitsuwan@ gmail.com

Mely Caballero-Anthony is Associate Professor and Head of the Centre for Non-Traditional Security (NTS) Studies at the S. Rajaratnam School of International Studies (RSIS), Nanyang Technological University, Singapore. She currently serves on the UN Secretary-General's Advisory Board on Disarmament Matters and Security. Her latest publications include "Understanding ASEAN Centrality" (Pacific Review, 2014) and Non-Traditional Security in Asia: Issues, Challenges and Framework for Action (co-edited with Alistair Cook) (ISEAS, 2013). E-mail: ismcanthony@ntu.edu.sg 
